\title{
Selenium in wheat from farming to food
}

1 Min Wang ${ }^{\mathrm{a}}$, Baoqiang $\mathrm{Li}^{\mathrm{b}}$, Shuang $\mathrm{Li}^{\mathrm{a}}$, Ziwei Song ${ }^{\mathrm{a}}$, Fanmei Kong ${ }^{\mathrm{a}}$ * Xiaocun Zhang ${ }^{\text {a }}$

$2 \quad{ }^{a}$ Shandong Agricultural University, No. 61, Daizong Street, Taian, 271018, Shandong

3 Province, China P.R.

$4 \quad$ b Linyi Academy of Agricultural Sciences, No. 351, Wuhe North Street, Lanshan District,

$5 \quad$ Linyi City, 276003, Shandong Province, China P.R.

$6 \quad$ Emall: fmkong@sdau.edu.cn; xczhang@sdau.edu.cn.

7 Abstract: Selenium (Se) plays an important role in human health. Approximately $80 \%$ of the world's population does not consume enough Se which recommended by WHO (World Health

9 Organization). Wheat is an important staple food and Se source for most people in the world.

This article summarizes literatures about Se from 1936 to 2020 to investigate Se in wheat farming soil, wheat, and its derived foods. Se fortification and the recommended Se level in wheat were also discussed. Results showed that Se contents in wheat farming soil, grain, and its derived foods around the world were 3.8-552 (mean, 220.99), 0-8,270 (mean, 347.30), and effectively realize Se fortification in wheat. The contents in grain, flour, and its derived foods could be improved from 93.94 to $1,181.92,73.06$ to $1,007.75$, and 86.90 to $587.61 \mu \mathrm{g} \cdot \mathrm{kg}^{-1}$ in average after leaf Se fertilizer application in the field. There was a significant positive correlation between Se content in farming soil and grain, and it was extremely the same between foliar Se fertilizer concentration rate and grain Se increased rate. The recommended Se fortification level in cultivation of wheat in China, India, and Spain was 18.53-23.96, $21 \quad 2.65-3.37$, and 3.93-9.88 $\mathrm{g} \cdot \mathrm{hm}^{-2}$ respectively. Milling processing and food type could greatly 
affect Se content of wheat derived food and should be considered seriously to meet people's Se requirement by wheat.

Keywords: Se, soil, grain, flour, fortification, bioavailability

Selenium (Se) is a metalloid element of group VI A in the fourth period of the periodic table of the elements. It was first discovered by Swedish scientist Berzelius JJ in 1817 and named it after the Selene, the goddess moon ${ }^{1}$. However, researchers discovered in 1934 that the "alkaline soil disease" and "stumble" of animals were caused by excessive intake of Se. Since then, research on Se has mainly been based on its toxicity ${ }^{2}$. In 1860 s, Se was determined as an essential element in animals and human bodies and has gradually gained widespread attention worldwide ${ }^{3}$. Se is one of the 14 essential trace elements in human body which constitutes a series of important Se-containing proteins and enzymes in galacturids ${ }^{4}$ although the total amount of it in the human body is only $14-20 \mathrm{mg}^{4}$. Se is closely related to the health and Se deficiency can cause more than 40 kinds of diseases, such as Keshan disease, large bone nodule disease, anemia, infertility, and muscular dystrophy ${ }^{6}$. Moreover, excessive Se intake can cause hair and nail loss, skin ulceration, nerve damage, and other toxic symptoms ${ }^{7}$. Therefore, a safe and suitable daily Se intake should be maintained and 50-400 $\mu \mathrm{g} / \mathrm{day}$ of Se intake is safe and suitable according to the recommendations of World Health Organization $(\mathrm{WHO})^{8}$. Se deficiency is widely observed in more than 40 countries around the world, and approximately $80 \%$ of the population is Se deficient ${ }^{9}$. The most direct source to get Se is through dietary intake though Se bioavailability in human body varies widely $(10 \%-85 \%)^{10}$. Therefore, improving the Se deficient situation of people through safe Se-rich diet is an effective and long-term task. 
Wheat is the second largest food crop in population consumption ${ }^{11}$, and it provides nearly $50 \%$ daily calorie intake in most developing countries and more than $70 \%$ calorie intake in rural areas ${ }^{12}$. Wheat has strong Se enrichment capacity. It can produce high-security organic Se by absorbing Se in soil or foliage and store them in grains ${ }^{12}$. Se is mainly combined with protein in wheat grain and more evenly distributed throughout the whole grain than other minerals ${ }^{14}$. Therefore, unlike other micronutrients, most of the Se found in wheat grains can be retained in the flour, rather than being lost to the bran and aleurone layer during milling. Hence, it is an effective way to improve Se intake of people through Se enriched wheat.

Se fortification of wheat is a comprehensive and multi-objective process. Generally, the final effects of wheat Se fortification (Se content in the food) can be significantly affected mainly by three processes, including grain Se enriching in the field, grain grinding, and wheat-derived food processing. This article summarized reports related to the Se fortification of wheat, and discussed the main influencing factors, possible regulation measures and some relatively safe and suitable reference during the above three processes. The data of Se bioavailability was also discussed.

\section{MATERIALS AND METHODS}

\subsection{Data collection}

The papers relation to Se of wheat grain, flour and wheat derived foods published between 1936 and 2020 were used to set up the database by a literature search using Wiley, ACS, Science Direct, Springer Link and China National Knowledge Infrastructure (CNKI). Search keywords included different combinations, "wheat" AND "Selenium" or "flour" AND "Selenium" or "food" AND "Selenium". Selection criteria included: a) Field experiment: 
report wheat harvest time, wheat type and fertilization type, including soil $\mathrm{pH}$ and Se content;

b) wheat milling: report Se fertilizer type and Se content in different components after milling; and c) Food processing: report the source of wheat flour, food type, and Se content in food.

\subsection{Data Classification}

In selected reports, we summarized these data from soil to grain, milling, then to food under different conditions. A total of 66 research papers and 1066 paired observations were obtained (Figure 1); Grain Se content in different countries came from 41 references (Table S1); Se content of different wheat milling components were also obtained under different peeling and flour milling processing were got in 20 papers (Table S2); Se content of six kinds of different foods under different flour processing were obtained from 26 reports (Table S3). Total of 117 paired observations for the effects of soil Se on wheat grain from 21 articles, and 188 paired data for the effects of different Se fertilizer on wheat grain from 21 articles were extracted.

\subsection{Data management}

The database was established using Excel 2019 software. OriginPro 8.5 and PowerPoint 2019 software were used to draw graphics. All statistical analyses were performed using SPSS 18.0 software.

\section{RESULT AND DISCUSSION}

\subsection{Se content in wheat grain}

Se content in wheat grain was $0-1500 \mu \mathrm{g} \cdot \mathrm{kg}^{-1}\left(110.98 \mu \mathrm{g} \cdot \mathrm{kg}^{-1}\right.$ in average $)$ in the world ${ }^{8}$ ${ }^{15-50}$. The average Se content was lower than that suggested by the reference of Se-rich grains $\left(200-300 \mu \mathrm{g} \cdot \mathrm{kg}^{-1}\right)^{39}$. The large variance of Se content in wheat grain was mainly attributed the 
difference of wheat varieties, area, basic properties of soil, and Se biological strengthening measures in the field.

\subsubsection{Variance of Se content among different wheat varieties}

Generally, the old and new varieties might have different potentials to accumulate Se in grain. According to our data, grain Se content in wheat reported in 1936-2000 could reach $198.76 \mu \mathrm{g} \cdot \mathrm{kg}^{-1}$ in average, and this value was significantly higher than that in $2001-2020$ (Figure 1a). "Green Revolution", which began in the 1950s, dramatically increased crop production $^{51}$ and the "dilution effect" caused by the increase of yield might be the most important reason for the decrease of Se content in new varieties. In addition, different wheat varieties have different ability to accumulate Se under the same soil environment. For example, black grain wheat Se content was $177.34 \mu \mathrm{g} \cdot \mathrm{kg}^{-1}$, which was significantly higher than that in white grain $\left(70.29 \mu \mathrm{g} \cdot \mathrm{kg}^{-1}\right)^{33}$.

\subsubsection{Grain Se content of wheat in different continents and countries}

No significant difference was observed among the average grain Se contents of wheat in $\operatorname{Asia}^{8,15-20,22-25,27-29,31,33-40,43}\left(63.36 \mu \mathrm{g} \cdot \mathrm{kg}^{-1}\right)$, Africa $^{8,15-20,22-25,27-29,31,33-40,43}\left(64.15 \mu \mathrm{g} \cdot \mathrm{kg}^{-1}\right)$, and Europe $^{20,22,26,29,30,41,42,44,46,48,50}\left(85.98 \mu \mathrm{g} \cdot \mathrm{kg}^{-1}\right)$, and these values which were all lower than the normal level $\left(100 \mu \mathrm{g} \cdot \mathrm{kg}^{-139}\right)$. There was a significant difference among the grain Se content in South America ${ }^{22,50}$, North America ${ }^{20,22,47,49,50}$, and Oceania ${ }^{22,45,50}$ with values of $600.00,286.23$, and $194.80 \mu \mathrm{g} \cdot \mathrm{kg}^{-1}$, respectively (Figure 2). These values were significantly higher than that in Asia, Africa, and Europe. Grain Se content in different countries on the same continent varied greatly too. For Europe, the grain Se content in Spain, Slovakia, Portugal, and Norway were 26.75-93.90 $\mu \mathrm{g} \cdot \mathrm{kg}^{-1}$, but that in Italy was $133.44 \mu \mathrm{g} \cdot \mathrm{kg}^{-1}$. 


\subsubsection{Basic properties of soil affecting grain Se content of wheat}

Soil Se content and $\mathrm{pH}$ are the basic properties of soil which can significantly affect Se content in wheat grain. The total soil Se content varied greatly among different regions. $0-175,175-450,450-2,000$, and 2,000-3,000 $\mu \mathrm{g} \cdot \mathrm{kg}^{-1}$, respectively ${ }^{28}$. The soil in most parts of the world is Se-deficient. For instance, soil Se contents in Italy, China, India, and South Africa are $130,21.2112 .60$, and $6.14 \mu \mathrm{g} \cdot \mathrm{kg}^{-1}$, respectively. Globally, soil Se content in farming

117 system is $10-2,000 \mu \mathrm{g} \cdot \mathrm{kg}^{-1}\left(300 \mu \mathrm{g} \cdot \mathrm{kg}^{-1} \text { in average }\right)^{28}$, while that in farming soil of wheat is $3.80-552.00 \mu \mathrm{g} \cdot \mathrm{kg}^{-1}$. There was a significant positive correlation between soil Se content and grain Se content (Figure 3). Se content of wheat grain from the soil with Se content of 0-200 $\mu \mathrm{g} \cdot \mathrm{kg}^{-1}$ was significantly lower than that from the soil with Se content of $200-400 \mu \mathrm{g} \cdot \mathrm{kg}^{-1}$ and 400-600 $\mu \mathrm{g} \cdot \mathrm{kg}^{-1}$, but no significant difference was observed between that from the soil with Se contents of $200-400 \mu \mathrm{g} \cdot \mathrm{kg}^{-1}$ and $400-600 \mu \mathrm{g} \cdot \mathrm{kg}^{-1}$ (Figure 1a). was observed in wheat grain Se content among neutral soil $(\mathrm{pH}$ 6.5-7.5), alkaline soil

$127\left(55.50 \mu \mathrm{g} \cdot \mathrm{kg}^{-1}\right)$ (Figure 1a). Acid soil occupies approximately $30 \%$ of the world's ice-free land 128 area and occurs mainly in tropical and subtropical regions. These acid soils are more likely to be Se-deficient ${ }^{53}$. 
132 cultivated soils in the world are Se insufficient, so applying Se fertilizer to enhance Se content

133 in wheat grains is the preferred route to consider.

134

135

\subsubsection{Effects of different Se fertilization on grain Se content in wheat}

The process of improving grain Se by fertilizer in the field is the most important part in Se fortification. Se fertilization treatment during wheat growth can significantly increase grain Se content according to the data about the grain Se contents in wheat around the world since 1936 (Table S1). The grain Se content of wheat planted in natural soil without Se fertilization treatment was about $0-1,500.00 \mu \mathrm{g} \cdot \mathrm{kg}^{-1}\left(110.98 \mu \mathrm{g} \cdot \mathrm{kg}^{-1} \text { in average }\right)^{8,15-50}$, and that reached $58.00-8,270.00 \mu \mathrm{g} \cdot \mathrm{kg}^{-1}\left(677.21 \mu \mathrm{g} \cdot \mathrm{kg}^{-1}\right.$ in average $)$ with Se fertilization treatment.

However, significant differences were observed in the effect of different Se fertilizer treatments and most of the reports indicated that foliar Se fertilization treatment might be the most effective way to improve grain Se content ${ }^{8,15,20,26,29,35,36,52}$. Grain Se content with foliar Se fertilization treatment was significantly higher than that of soil Se fertilization treatment and CK (Figure 1a). Se content in the wheat grain with soil Se fertilization treatment was $190.00-6,090.00 \mu \mathrm{g} \cdot \mathrm{kg}^{-1}\left(528.87 \mu \mathrm{g} \cdot \mathrm{kg}^{-1} \text { in average }\right)^{19,28,29,38,42,48,54}$, that with foliar Se fertilization treatment was $58.00-8,270.00 \mu \mathrm{g} \cdot \mathrm{kg}^{-1}\left(729.69 \mu \mathrm{g} \cdot \mathrm{kg}^{-1} \text { in average }\right)^{8,13,15,16,18-20,23-31 \text {, }}$ $35-38,52,54$, and that with seed Se soaking treatment was only $64.80-300.00 \mu \mathrm{g} \cdot \mathrm{kg}^{-1}(128.67$ $\mu \mathrm{g} \cdot \mathrm{kg}^{-1}$ in average $)^{39,55}$. A positive correlation was observed between foliar Se fertilizer application amount and grain Se content growth rate, and this correlation can be expressed with the equation $Y=22.20587 X$ (Figure 4a). But there was no significant correlation between soil Se fertilization and grain Se content, which correlation can be expressed with the equation $Y=0.0157 X$. The use of foliar Se fertilizer was an environmentally safe and effective because 
154 of its low concentration in solution, effective absorption, and more accurate control of total Se

155 application. Using $100 \mathrm{~g} \mathrm{Se} \cdot \mathrm{hm}^{-2}$ for foliar fertilization, grain Se content is $1770 \mu \mathrm{g} \cdot \mathrm{kg}^{-1}$; but

156 the same Se dosage for soil fertilization, grain Se content is only $1064 \mu \mathrm{g} \cdot \mathrm{kg}^{-129}$. The foliar Se

157 fertilizer is the most popular method in Se fortification. Moreover, $\mathrm{Na}_{2} \mathrm{SeO}_{3}$ is the most

158 common form of foliar Se fertilizer for its lower toxicity than $\mathrm{Na}_{2} \mathrm{SeO}_{4}$.

159 The grain Se content in different countries increased significantly after Se fortification in

160 the field (Figure $4 \mathrm{~b}$ ), and this value increased from $93.94 \mu \mathrm{g} \cdot \mathrm{kg}^{-1}$ to $1181.92 \mu \mathrm{g} \cdot \mathrm{kg}^{-1} \mathrm{after} \mathrm{Se}$

161 fortification. A large variance in Se fortification effects was observed in different countries. For

162 example, the grain Se content increased in Pakistan, India, Turkey, Spain, South Africa,

163 Norway, Portugal, Slovakia, China, and Italy by 2.16-25.98 times and that in Pakistan and

164 Italy was 2.16 and 25.98 times, respectively.

165 In addition to the Se application amount, Se concentration is also an important factor

166 affecting the effect of foliar fertilizer for one wheat variety. Wheat Se content can reach the

167 standard of Se fortification by foliar fertilizer application (Se concentration: $40 \mathrm{mg} \mathrm{Se} \cdot \mathrm{L}^{-1}$,

168 application rate: $750 \mathrm{~kg} \cdot \mathrm{hm}^{-2}$ ) at the early filling stage. Hence, the determination of the

169 appropriate application concentration and amount of foliar fertilizer are both the key to the

170 effect of Se nutrient enhancement of wheat.

\subsection{Se in flour and its influencing factors}

172 The proportion of Se in wheat grains that can be directly ingested by the human body is

173 also a key link for human Se supplementation. Most of the wheat will be ground into flour, and

174 then be made into different foods. Wheat grain is generally divided into bran, embryo, and

175 endosperm, accounting for $14 \%-16 \%, 2 \%-3 \%$, and $81 \%-84 \%$ of the grain weight, 
176

177

178

respectively ${ }^{29}$. During milling, wheat grains are peeled off. The bran, which consists of the seed coat, aleurone layer and embryo, are then stripped off. Se content in bran was $15.00-520.00 \mu \mathrm{g} \cdot \mathrm{kg}^{-1}\left(149.48 \mu \mathrm{g} \cdot \mathrm{kg}^{-1} \text { in average }\right)^{13,19,26,28,45}$, which was significantly higher than that in flour $\left(101.02 \mu \mathrm{g} \cdot \mathrm{kg}^{-1} \text { in average }\right)^{13,19,26,28,30,41,45,56-67}$. There were also some reports indicated that Se content in bran is approximately three times higher than that in flour after grinding $^{19,26,45}$. It was clear that, there should have a part of Se loss during the milling process. Different wheat milling methods remarkably affect flour Se content (Figure 1 b). Flour can mainly be divided into two types, namely, whole wheat flour and standard flour, according to the milling method. Se content in standard flour was significantly lower than that in whole wheat flour. According to our results (Table S2), Se content in standard flour was $13.00-500.00 \mu \mathrm{g} \cdot \mathrm{kg}^{-1}\left(101.02 \mu \mathrm{g} \cdot \mathrm{kg}^{-1} \text { in average }\right)^{13,19,26,28,30,41,45,56-67}$, and the whole wheat flour Se content was $35.60-650.00 \mu \mathrm{g} \cdot \mathrm{kg}^{-1}\left(227.58 \mu \mathrm{g} \cdot \mathrm{kg}^{-1} \text { in average }\right)^{26,57,62,64,66,68}$. Flour road during flour milling can be divided into six flour parts (i.e., three "Broken [B]" and three "Reduced [R]" milling parts) and two kinds of bran parts (i.e., bran and shorts). A significant difference was observed among the ingredients in different flour roads. The flour collected by B1, R1, B2, R2, B3, and R3 was standard flour, the flour collected by B1, R1, B2, and B3 was bread flour, and the flour from B1 and R1 was refined flour ${ }^{26,57,62,64,66,68}$. The Se content in different components after wheat milling can be arranged as follows: B flour $>\mathrm{R}$ flour. The Se contents of flour from R1, R2, R3, B1, B2, and B3 were 106.85, 128.32, 207.90, 89.00, 96.82, and $128.29 \mu \mathrm{g} \cdot \mathrm{kg}^{-1}$ in average, respectively. The Se content of flour in common flour roads was $\mathrm{B} 3>\mathrm{B} 2>\mathrm{R} 3>\mathrm{B} 1>\mathrm{R} 2>\mathrm{R} 1^{57,69}$. The rate of Se concentration loss and Se content loss in wheat milling were $17.19 \%$ and $46.40 \%$, respectively. Most of the published literature used Se 
concentration loss, and a few studies have focused on Se content loss. The peeling rate of $4 \%-5 \%$ can effectively increase standard flour Se content. When the peeling rate was greater than 9\%, no significant difference was observed in the Se content between standard flour and unpeeled flour ${ }^{19}$.

Se content in standard flour and the products in each flour road can be greatly affected by grain Se content. Se contents in whole wheat flour and standard flour in the Se-rich grain with foliar Se fortification treatment were significantly higher than that in the control treatments, and increased from $227.58 \mu \mathrm{g} \cdot \mathrm{kg}^{-1}$ to $1,110.03 \mu \mathrm{g} \cdot \mathrm{kg}^{-1}$ and from $101.02 \mu \mathrm{g} \cdot \mathrm{kg}^{-1}$ to 714.90 $\mu \mathrm{g} \cdot \mathrm{kg}^{-1}$ respectively (Figure $1 \mathrm{~b}$ ). The Se contents in the products of different flour roads for the Se-enhancing grain from foliar Se fortification could be arranged as B2>R3>B1>R2>R1, which was quite different with that of common flour. The average rates of Se concentration and content loss in wheat milling were $15.04 \%$ and $38.56 \%$, respectively, after Se fortification treatment.

Therefore, milling methods might affect flour Se content, and foliar Se fortification can greatly improve Se content in standard flour and change the Se distribution in products of different flour roads.

\subsection{Se in wheat derived foods}

Flour is generally used for the preparation of foods, such as bread, noodles, and biscuits. These staple foods play an important role in people's diet. For example, wheat-related traditional foods account for $75 \%$ of the total wheat consumption in $\mathrm{China}^{34}$. Se content in wheat-derived foods was $3.60-1130.00 \mu \mathrm{g} \cdot \mathrm{kg}^{-1}$ with an average of $191.87 \mu \mathrm{g} \cdot \mathrm{kg}^{-113,30,41,45,46,57}$, 59-62, 64-67,70-81 according to the data over the past 50 years (Table S3). There was a significant 
difference for the Se content of different wheat-derived foods (Figure 5). Cooking foods has the highest Se content which can reach $382.83 \mu \mathrm{g} \cdot \mathrm{kg}^{-1}$, and it was significantly higher than that in baked foods $\left(244.98 \mu \mathrm{g} \cdot \mathrm{kg}^{-1}\right)$. In addition, the average Se contents in pasta, noodles, biscuits, and bread also can achieve $325.45,251.53,181.65$, and $137.51 \mu \mathrm{g} \cdot \mathrm{kg}^{-1}$, respectively.

High temperature can result in the volatilization of $\mathrm{Se}^{83}$. Hence, Se loss in wheat-derived foods processing is mainly occurs during heating, especially under the dual effect of dissolution and heat volatilization when cooking, steaming, and frying the same food ${ }^{82,83}$. Moreover, soaking steps in food fermentation also can reduce wheat-derived foods Se content. For example, Se content in mung bean and millet would decrease by $7.17 \%$ and $2.62 \%$, respectively during soaking ${ }^{83}$. But no report about the change of Se in wheat grain during soaking and the flour fermentation was retrieved.

In addition, increasing grain Se content through foliar Se fortification can effectively improve Se content in wheat-derived foods (Figure 1c). For example, Se content in pasta increased from $22.4 \mu \mathrm{g} \cdot \mathrm{kg}^{-1}$ to $424.43 \mu \mathrm{g} \cdot \mathrm{kg}^{-1}$ (17.94 times) and that in bread increased from $119.15 \mu \mathrm{g} \cdot \mathrm{kg}^{-1}$ to $644.69 \mu \mathrm{g} \cdot \mathrm{kg}^{-1}$ (4.41 times) using the flour derived from foliar Se fortification. Hart et al. ${ }^{57}$ found that foliar Se application rate is positively correlated with bread Se content, and their relationship can be expressed using the formula $Y=19.2262 X+95.95332$. Food processing can greatly affect Se content in food, and increasing Se content in grain through foliar Se fortification is an effective way to improve Se content in wheat-derived foods.

\subsection{Se bioavailability}



absorbed Se to total intake Se is called bioavailability ${ }^{10}$. The Se from food can be effectively used by the human body only through the absorption in blood circulation or tissues and then different Se types. Se in wheat-derived foods mainly can be divided into inorganic Se (i.e., selenite) and organic Se (i.e., SeMet). Organic SeMet is the main form in wheat grain, flour, and wheat-derived foods, which accounts for $70 \%-90 \%{ }^{14,84}, 59 \%-82 \%{ }^{43,78,85,86}$, and $42 \%-83 \%{ }^{43,57,85}$ of total Se, respectively. bioavailability. Organic Se is the mainly forms which can be actively absorbed by human small intestine, and the bioavailability generally fluctuates between $70 \%$ and $90 \%{ }^{43,57,85}$. Inorganic Se can be absorbed via simple absorption (selenite) and passive diffusion (selenite), and the bioavailability is generally less than $50 \%^{87}$. Moreover, the long-term consumption of inorganic Se may result in toxic and side effects ${ }^{10}$. The molecular of $\mathrm{H}_{2} \mathrm{Se}$ is the key in the Se metabolism of human body. The role of $\mathrm{H}_{2} \mathrm{Se}$ mainly includes : 1) $\mathrm{H}_{2} \mathrm{Se}$ first transforms to selenite and SeMet form, and then synthesizes selenoprotein in liver and 2) SeMet and SeMeCys catalyze $\mathrm{H}_{2} \mathrm{Se}$ to form different Se ions forms under continuous methylation, which digestion model ${ }^{88,89}$, Caco-2 based cell model ${ }^{91}$, animal models ${ }^{92}$, and human Se bioavailability 
flour was also very high, which values was $75.4 \%-91.8 \%{ }^{94}$. The consecutive consumption of

Se-enriched wheat for six weeks could significantly increase human serum Se content, but

Se-enriched fish had no obvious effect ${ }^{93}$. Generally, SeMet can be effectively absorbed by

digestion method to simulate bread digestion, soluble Se content after gastric and

gastrointestinal digestion accounted for $75 \%$ and $89 \%$ of total Se content in bread, respectively, and SeMet accounted for $95.5 \%$ and $96.8 \%$ of soluble $\mathrm{Se}^{93}$. ascribed to the following factors: 1) Se type in food - different Se types showed different bioavailability. For instance, SeMet and SeMeCys have a bioavailable of up to $90 \%{ }^{92}$. The bioavailability of SeMet is approximately 1.5 -fold higher than that of selenite ${ }^{96} .100 \%$ of

274 selenate can be taken up, but a significant fraction will be excreted in the urine. Yet, the direct 275 absorption of selenite is approximately 50\%-60\% ${ }^{97}$ 2) Food type - a high-fat diet can hinder 276 Se absorption, resulting in low Se bioavailability ${ }^{90}$. 3) Food processing - heat treatment not 277 only affects total Se content but also reduced Se antagonist content. However, it's worth noting 278 that proper heat treatment might improve Se bioavailability too ${ }^{92}$. 4) Antagonism with other 279 minerals - Ca intake in the human body would reduce Se bioavailability. Meanwhile, Vc can 280 transform selenate into insoluble Se compounds in a short time, thus reducing $\mathrm{Se}$ 281 bioavailability ${ }^{98}$. 5) Digestion and absorption capacity of human body. For instance, 282 gastrointestinal diseases will reduce Se bioavailability ${ }^{98}$.

283 The reports above indicated that wheat-related foods were effective Se source for people 284 because most of the Se in wheat-related foods are organic SeMet which has high 
bioavailability. So, improving Se content in the wheat grain by foliar Se fortification is the key step and effective way to supplement Se in human body in most of the Se deficient areas.

\subsection{Suitable level of Se in wheat grain and in fertilizer applied in the field}

Both insufficient and excessive Se intake will have adverse effects on human health. Therefore, it should be seriously considered about the suitable Se level in the grain of wheat and the proper Se fertilizer quantity in the field which can be determined according to some important factors including the proper Se intake quantity per capita, dietary pattern, wheat Se accumulation efficiency and Se loss in food processing etc.

The range of Se intake recommended by WHO is $50-400 \mu \mathrm{g} /$ day and this can be the reference to determine the proper Se intake quantity per capita of people. Dietary pattern, which refers to the combination of various forms of food ingredients used in people's actual life, should also be considered ${ }^{100,101}$. The representative dietary patterns are divided into Western, Oriental, and Mediterranean dietary patterns. Western dietary patterns are mainly characterized by the intake of large amounts of red meat, processed meat products, refined cereals, desserts, French fries, and high-fat dairy products. Oriental dietary patterns are mainly characterized by the intake of a large number of fruits, vegetables, legumes, whole wheat, an appropriate amount of fish, and poultry. Mediterranean dietary patterns are mainly characterized by the intake of monounsaturated fatty acids rich in olive and olive oil, whole grains, fruits, vegetables and dairy products, weekly intake of fish, poultry, nuts, and legumes. The distribution law of food Se content is as follows ${ }^{62}$ : fish $>$ meat $>$ egg $>$ cereal $>$ fruits and vegetables. Hence, the actual Se intake per capita in western dietary patterns countries could reach the recommended level. The actual Se intake per capita in some Mediterranean dietary 
307

pattern countries also could reach the recommended level, such as Italy, but some countries such as Spain cannot not reach the recommended level. While the actual Se intake per capita in Oriental dietary patterns countries, such as China and India, did not reach the recommended level.

With wheat as Se source, the level of Se needed in wheat grains and the amount of Se to be applied in the field should be determined.

Daily insufficient Se intake $=$ Recommended Se intake per capita-Actual Se intake per capita

Total Se loss rate

$$
=\frac{\text { Unit weight of grain } \times \text { Grain Se content }- \text { Unit weight of grain } \times \text { Flour extraction } \times \text { Flour Se content }}{\text { Unit weight of grain } \times \text { Grain Se content }} \times 100 \%
$$

Recommended grain intake per capita $=\frac{\text { Recommended flour intake per capita }}{\text { Flour extraction }}$

Suitable Se fortification Level in grain

$$
=\frac{\text { Daily insufficient Se intake }+ \text { Actual Se intake per capita }+ \text { proportion of Se intake by grain (daily Se intake) }}{\text { Recommended grain intake per capita } \times(1 \text {-Total Se loss rate })}
$$

The recommended Se intake per capita is $60-400 \mu \mathrm{g} \cdot \mathrm{day}^{-1}$, the recommended Se in grain is $150 \mathrm{~g}$ (assuming all for wheat), the actual Se intake is $43.90 \mu \mathrm{g} \cdot \mathrm{kg}^{-1}$, and the grain daily Se intake accounts for approximately $22.6 \%$ in China according to the national nutrition and health guidelines. The upper limit of Se content in wheat grain is $300 \mu \mathrm{g} \cdot \mathrm{kg}^{-1}$, and the scope of Se content in wheat grain is $242.74-300.00 \mu \mathrm{g} \cdot \mathrm{kg}^{-1}$ in China. According to the formula and the parameters, the amount of Se fortification by foliar Se fertilizer in China should be $18.53-23.96 \mathrm{~g} \cdot \mathrm{hm}^{-2}$ to meet people's daily need. The result varied widely between different countries, for example, the amount of Se fortification should be 2.65-3.37 and 3.93-9.88 $\mathrm{g} \cdot \mathrm{hm}{ }^{-2}$ in India and Spain, respectively (Figure 7, Table $1^{8,98,102-107}$ ). 
Table 1 Recommended amount of wheat Se fertilizer in different countries

\begin{tabular}{|c|c|c|c|c|c|c|}
\hline $\begin{array}{l}\text { Dietary } \\
\text { pattern }\end{array}$ & Country & $\begin{array}{c}\text { Recommended } \\
\text { daily Se intake per } \\
\text { capita }\left(\mu \mathrm{g} \cdot \mathbf{d}^{-1}\right)\end{array}$ & $\begin{array}{c}\text { Wheat grain } \\
\text { Se content } \\
\left(\mu \mathrm{g} \cdot \mathrm{kg}^{-1}\right)\end{array}$ & $\begin{array}{c}\text { Actual Se } \\
\text { intake per } \\
\text { capita }\left(\mu \mathrm{g} \cdot \mathbf{d}^{-1}\right)\end{array}$ & $\begin{array}{l}\text { Recommended } \\
\text { wheat grain Se } \\
\text { content }\left(\mu \mathrm{g} \cdot \mathrm{kg}^{-1}\right)\end{array}$ & $\begin{array}{l}\text { Recommended Se } \\
\text { fertilizer applying } \\
\text { amount }\left(\mathrm{g} \cdot \mathrm{hm}^{-2}\right)\end{array}$ \\
\hline $\begin{array}{l}\text { Oriental } \\
\text { dietary }\end{array}$ & China & $60.00^{100}$ & 47.46 & $43.90^{97}$ & $242.74-300.00$ & $18.53-23.96$ \\
\hline patterns & India & $50.00^{8}$ & 171.70 & $48.00^{98}$ & $272.76-300.00$ & $2.65-3.37$ \\
\hline \multirow{2}{*}{$\begin{array}{c}\text { Mediterranean } \\
\text { dietary } \\
\text { patterns }\end{array}$} & Spain & $50.00^{8}$ & 93.90 & $49.24^{95}$ & $175.84-300.00$ & $3.93-9.88$ \\
\hline & Italy & $50.00^{8}$ & 133.44 & $66.53^{96}$ & $\begin{array}{l}\text { No need to } \\
\text { fortification }\end{array}$ & $\begin{array}{l}\text { No need to } \\
\text { fortification }\end{array}$ \\
\hline \multirow{2}{*}{$\begin{array}{l}\text { Western } \\
\text { dietary } \\
\text { patterns }\end{array}$} & Australia & $55.00^{92}$ & 191.83 & $57.00^{99}$ & $\begin{array}{l}\text { No need to } \\
\text { fortification }\end{array}$ & $\begin{array}{l}\text { No need to } \\
\text { fortification }\end{array}$ \\
\hline & America & $55.00^{92}$ & 304.95 & $80.00^{98}$ & $\begin{array}{l}\text { No need to } \\
\text { fortification }\end{array}$ & $\begin{array}{l}\text { No need to } \\
\text { fortification }\end{array}$ \\
\hline
\end{tabular}

324

\section{CONCLUSION AND FUTURE TRENDS}

All the reports now showed that Se nutrition enhancement of human body through the consumption of wheat in the diet is an effective and feasible way. But the effects were mainly influenced by three important processes, including 1) the acquisition of Se-rich wheat grains, 2) reduction of Se loss in the process of flour milling and food processing, 3) the improvement of bioavailability of Se in food. There were many confirmed conclusions we can make and also many further researches needed to conduct in the future based on the above three aspects.

1) The acquisition of Se-rich wheat grains. It was the most important step in Se fortification. Application of Se foliar fertilizer is the first choice which is more effective and economic to get Se-rich grain than soil fertilization according to the available reports. The 
application of foliar fertilizer $750 \mathrm{~kg} \cdot \mathrm{hm}^{-2}$ with Se concentration $40 \mathrm{mg} \cdot \mathrm{L}^{-1}$ at the early filling stage can most likely make grain Se content reach $200-300 \mu \mathrm{g} \cdot \mathrm{kg}^{-1}$. How to improve Se efficiency of soil in the cultivation of wheat is another aspect needed further concentration. It was necessary to further investigate the relationship between soil properties and Se bioavailability for the plants in the soil, and these research combined with other special methods might be helpful to improve Se efficiency of soil. In addition, the wheat varieties are another important factor which should be considered seriously. Many reports confirmed the large variance between different wheat varieties ${ }^{33}$. The grain Se content of the varieties with high Se accumulation potential was $742.33 \%$ higher than that of wheat varieties with low Se accumulation $^{8}$. Therefore, it's necessary to selection, breeding and application of wheat varieties with strong Se enrichment ability. Some genes/varieties related with high accumulation of Se in grain should be considered in breeding ${ }^{8}$. Few investigations were conducted on the effects of other nutrients on wheat Se accumulation such as foliar Se fortification increased grain $\mathrm{Se}$ and $\mathrm{Zn}$ content, but reduced grain $\mathrm{Cu}, \mathrm{Fe}, \mathrm{K}, \mathrm{Mg}$ and $\mathrm{S}$ content $^{109}$.

2) Reduction of Se loss in the process of flour milling and food processing. Flour Se content can be retained to the maximum extent when the peeling rate is $4 \%-5 \%$ and the milling ratio is $70 \%-80 \%$, and try to choose low temperature method to keep Se content in wheat derived-foods according to the available reports. But few reports focused on the mechanism of the effects on Se loss in different food processing methods.

3) The improvement of bioavailability of Se in food. The metabolism and regulation of different forms of Se in body and the interaction mechanism with other substances needed 
356 further investigation. The information will contribute to the other ways to supplement Se of

357 human body. For example, the addition of food additives can improve Se bioavailability in

358 food. This process should also be considered in the food industry.

359 Se deficiency is a worldwide problem. It is an effective and feasible way to supplement

360 Se for people through Se fortification in wheat. We can adopt the strategy including the above

361 three aspects to get enough Se from wheat. But this strategy needs more public attention, more

362 research and application results to achieve this goal.

363

364

365

366

367

\section{CONFILCT OF INTEREST}

The authors declare that the research was conducted in the absence of any commercial or financial relationships that could be construed as a potential conflict of interest.

\section{AUTHOR CONTRIBUTIONS}

MW, SL and ZWS collected and analysed data. MW, FMK and XCZ wrote this paper. XCZ, FMK and BQL conceived and modified this paper.

\section{ACKNOWLEDGMENTS}

This paper was supported by Agricultural Variety Improvement Project of Shandong Province (2019LZGC001) and Special Project of Regional Science and Technology Collaborative Innovation between District Science and Technology Department and Rikaze Municipal Government in 2020 (Research and Demonstration Application of Bioaugmentation Technology for trace nutrients of highland barley in Rikaze area).

\section{REFERENCE}

(1) Schwarz, K.; Foltz, C. M. Selenium as an integral part of factor 3 against dietary necrotic liver degeneration. J Am Chem Soc. 1957, 79, 3292-3293. 
(2) Zhang, J. J. The Biological functions of selenium and research development of se-enriched foodstuff. Studies of Trace Elements and Health. 2006, 23, 58-60. (In Chinese).

(3) Kilness, A. W. Selenium and public health. South Dakota Journal of Medicine. 1973, 26, $17-19$.

(4) Arteel, G. E.; Sies, H. The biochemistry of selenium and the glutathione system. Environ. Toxicol. Phar. 2001, 10, 153-158.

(5) Huang, Q. J.; Wang, S. S.; Zheng, W.; Dai, G. Z.; Yang, J. Research progress of selenium-rich in Wheat. J. Green Sci. Technol. 2015, 12, 73-76. (In Chinese).

(6) Rayman, M. P. The importance of selenium to human health. The Lancet. 2000, 356, 233-241.

(7) Johnson, L. J.; Meacham, S. L.; Kruskall, L. J. The Antioxidants-Vitamin C, Vitamin E, Selenium, and Carotenoids. J Agromedicine. 2003, 9, 65-82.

(8) Liu, H.; Yang, Y. E.; Wang, C. H.; Li, F. C.; Li, K. Y.; Yang, N.; Wang, S.; Wang, H.; He, J.; Dai, S. Selenium content of wheat grain and its regulation in different wheat production regions of china. Sci. Agric. Sin. 2016, 49, 1715-1728. (In Chinese).

(9) Stoffaneller, R.; Morse, N. L. A review of dietary selenium intake and selenium status in Europe and the Middle East. Nutrients. 2015, 7, 1494-1537.

(10) Li, Y. N.; Ma, L. Y.; Huang, K. L.; Luo, Y. B.; Mei, X. H. Research advancement on bioavailability of selenium in dietary sources. Food and Nutrition in China. 2019, 25, (09), 5-9. (In Chinese).

(11) Cardoso, R. C.; Fernandes, Â.; Gonzaléz-Paramás, A. M.; Barros, L.; Ferreira, I. F. R. Flour fortification for nutritional and health improvement: A review. Food Res. Int. 2019, 125, 
400

401

402

403

404

405

406

407

408

409

410

411

412

413

414

415

416

417

418

419

420

421

108576.

(12) Cakmak, I. Enrichment of cereal grains with zinc: Agronomic or genetic biofortification? Plant Soil. 2008, 302, 1-17.

(13) Wang, P.; Zhang, X. C.; Kong, F. M.; Shi, Y. X.; Dong, H. Z. Change research of selenium in the processing from grain to steamed bread. Current Biotechnology. 2016, 6, 422-427. (In Chinese).

(14) Cubadda, F.; Aureli, F.; Ciardullo, S.; D’Amato, M.; Raggi, A.; Acharya, R.; Reddy, R. A. V.; Prakash, N. T. Changes in Selenium Speciation Associated with Increasing Tissue Concentrations of Selenium in Wheat Grain. J. Agr. Food Chem. 2010, 58, 2295-2301.

(15) Wang, M.; Ali, F.; Wang, M. K.; Dinh, Q. T.; Liang, D. Understanding boosting selenium accumulation in Wheat (Triticum aestivum L.) following foliar selenium application at different stages, forms, and doses. Environ. Sci. Pollut. R. 2020, 27, 717-728.

(16) Zhang, P. P.; Ma, H. X.; Yao, J. B.; Zhang, P. Effects of selenium foliar spray on selenium distribution in milling fractions in common wheat. Acta Agric.Nucl. Sin. 2019, 33, 2254-2260. (In Chinese).

(17) Qin, C.; Shi, C.; Wan, Q. Y.; Wang, L.; Liu, A. Q.; An, C. X. Speciation analysis of selenium in selenium-enriched wheat by PLC-ICP-MS. Food R\&D. 2019, 40, 140-144. (In

\section{Chinese).}

(18) Dong, S. F.; Sun, M.; Zhao, J. M.; Bai, X.; Lu, P. F.; Gao, Z. Q.; Ren, A. X.; Hou, F. F.; Yin, X. B. Effects of sodium selenite application at anthesis stage on the growth characteristics and Se accumulation in wheat plants. J. Shanxi Agric. Univ. (Nat. Sci.). 2019, 39, 13-18. (In

\section{Chinese).}


(19) Chen, B. N. Research on the effect of selenium application technology in winter wheat. In: Huazhong Agricultural University. 2019. (In Chinese).

(20) Zou, C.; Du, Y.; Rashid, A.; Ram, H.; Savasli, E.; Pieterse, P. J.; Ortiz-Monasterio, I.; Yazici, A.; Kaur, C.; Mahmood, K.; Singh, S.; Le Roux, M. R.; Kuang, W.; Onder, O.; Kalayci, M.; Cakmak, I. Simultaneous Biofortification of Wheat with Zinc, Iodine, Selenium, and Iron through Foliar Treatment of a Micronutrient Cocktail in Six Countries. J. Agr. Food Chem. 2019, 67, 8096-8106.

(21) López-Bellido, F. J.; Sanchez, V.; Rivas, I.; López-Bellido, R. J.; López-Bellido, L. Wheat grain selenium content as affected by year and tillage system in a rainfed Mediterranean Vertisol. Field Crop. Res. 2019, 233, 41-48.

(22) Ji, H. T.; Wang, M.; Cao, Y.; Li, X. L.; Jiang, L. F.; Ma, X. F. Correlation analysis of Fe, Zn, Se mass fraction in Durum and Emmer Wheat. Acta Agric Bore-occ Sin. 2018, 27, 772-778.

\section{(In Chinese).}

(23) Wang, J. M.; Chen, H. Y.; Guo, J. J.; Wang, M.; Du, B.; Shi, L.; Xu, Y. Y.; Jiang, S. C.; Jiang, H. F.; Zhou, L.; Chen, H.; Xing, D. Y.; Xie, Y. M. Preliminary study on the effect of selenium foilar fertilizer on agronomic characters, yield and selenium content of wheat. Journal of Yangtze University (Natural Science Edition). 2018, 15, 1-4. (In Chinese).

(24) Feng, K.; Jia, L. L.; Jia, Y. H.; Erken, D. L. X. T.; Liu, J.; Shi, S. B. Effect of selenium application on yield and selenium content of spring wheat under different plantin. J. Triticeae Crops. 2018, 38, 834-840. (In Chinese).

(25) Jin, Y. F; Gao, B. D. Effect of selenium fertilizer on Se-enrich reaction and Se absorption and distribution of spring wheat. China Soils Fert. 2018, 274, 113-117. (In 
444

\section{Chinese).}

(26) De Vita, P.; Platani, C.; Fragasso, M.; Ficco, D. B. M.; Colecchia, S. A.; Del Nobile, M. A.; Padalino, L.; Di Gennaro, S.; Petrozza, A. Selenium-enriched durum wheat improves the nutritional profile of pasta without altering its organoleptic properties. Food Chem. 2017, 214, $374-382$.

(27) Zhang, R.; Liu, M. S.; Wang, R. C.; Li, S. L.; Wang, N.; Wang, J. M. Effect of foliar spraying of plant Se-nutrients on wheat yield and quality. J. Triticeae Crops. 2015, 35, 856-859.

\section{(In Chinese).}

(28) Yu, R. Effects of different valence selenium and its applications on wheat yield and selenium content in the typical selenium deficient area of the loess plateau. In: Northwest A\&F University. 2015. (In Chinese).

(29) Galinha, C.; María, S. M.; Adriano, M. P.; Maria, C. F.; Coutinho, S.; Benvindo, M.; Almeida, A. S.; Marí a, T. P.; Yolanda, M.; Wolterbeek, H. T. Characterization of selenium-enriched wheat by agronomic biofortification. J Food Sci Tech Mys. 2015, 52, 4236-4245.

(30) Poblaciones, M. J.; Rodrigo, S.; Santamaría, O.; Chen, Y.; McGrath, S. P. Agronomic selenium biofortification in Triticum durum under Mediterranean conditions: From grain to cooked pasta. Food Chem. 2014, 146, 378-384.

(31) Meng, L. M.; Yang, Z. G.; Zhang, K.; Sun, J. W.; Ji, T. H. Effect of application of race element fertilizer on wheat yield and content of trace elements. J Anhui Agric Sci. 2014, 14, 4283-4285. (In Chinese).

(32) Beladel, B.; Nedjimi, B.; Mansouri, A.; Tahtat, D.; Belamri, M.; Tchanchane, A.; 
Khelfaoui, F.; Benamar, M. E. A. Selenium content in wheat and estimation of the selenium daily intake in different regions of Algeria. Appl. Radiat. Isotopes. 2013, 71, 7-10.

(33) Pei, Z. Y.; Wen, H. Q.; Zhang, L. S.; Cheng, T. L.; Li, X. Study on rich selenium black kernel wheat donghei No.1. Seed. 2013, 32, 74-76. (In Chinese).

(34) Wang, X. X.; Jia, A. X.; Yu, Z. L. Distribution of mineral elements in wheat milling. Modern Flour Milling Industry. 2012, 26, 23-26. (In Chinese).

(35) Zhang, X.; Bu, D. N.; Li, R. N. Effects of foliar spraying microelement fertilizers on yield and quality of winter wheat. J. Triticeae Crops. 2012, 32, 747-749. (In Chinese).

(36) Zhang, J. Y.; Zhang, P. P.; Ma, H. X.; Yao, J. B.; Geng, Z. M. Effects of spraying micronutrients on yield,quality and micronutrient content in grain of wheat. Acta Agric. Jiangxi. 2012, 24, 64-66. (In Chinese).

(37) Zhang, Y. Effects of selenium and zinc fertilizer on yield and selenium absorption and accumulation in spring wheat. Guangxi Agric Sci. 2012, 43, 626-629. (In Chinese).

(38) Tang, Y. X.; Wang, H. M.; Yang, J. F.; Lv, Y. H. Studies on the selenium content and selenium enriched technique of winter wheat in hebei province. J. Triticeae Crops. 2011, 31, 347-351. (In Chinese).

(39) Tang, Y. X.; Wang, H. M.; Lv, Y. H.; Liu, Q. L.; Yang, J. F. Effects of selenium seed soaking on growth, yield and seeds selenium content of wheat. J. Triticeae Crops. 2010, 30, 731-734. (In Chinese).

(40) Lu, L.; Ji, Y. M.; Li, L. R.; Li, Z. L.; Wu, Y. Analysis of Fe, Zn and Se contents in different wheat cultivars (Lines) planted in different areas. Chinese Journal of Applied \& Environmental Biology. 2010, 16, 646-649. (In Chinese). 
(41) Cubadda, F.; Aureli, F.; Raggi, A.; Carcea, M. Effect of milling, pasta making and cooking on minerals in durum wheat. J. Cereal Sci. 2009, 49, 92-97.

(42) Ducsay, L.; Lozek, O.; Varga, L. The influence of selenium soil application on its content in spring wheat. Plant Soil \& Environment. 2009, 55, 80-84.

(43) Yadav, S. K.; Singh, I.; Sharma, A.; Singh, D. Selenium status in food grains of northern districts of India. J. Environ. Manage. 2008, 88, 770-774.

(44) Spadoni, M.; Voltaggio, M.; Carcea, M.; Coni, E.; Raggi, A.; Cubadda, F. Bioaccessible selenium in Italian agricultural soils: Comparison of the biogeochemical approach with a regression model based on geochemical and pedoclimatic variables. Sci. Total Environ. 2007, $376,160-177$.

(45) Lyons, G.; Ortiz-Monasterio, I.; Stangoulis, J.; Graham, R. Selenium concentration in wheat grain: Is there sufficient genotypic variation to use in breeding? Plant \& Soil. 2005, 269, 369-380.

(46) Díaz-Alarcón, J. P.; Navarro-Alarcón, M.; Lbpez-Garcia de la Serrana, H.; López-Martínez, M. C. Determination of selenium in cereals, legumes and dry fruits from southeastern Spain for calculation of daily dietary intake. Sci. Total Environ. 1996, 184, 183-189.

(47) Wyatt, C. J.; Meléndez, J. M.; Acu A, N.; Rascon, A. Selenium (Se) in foods in northern Mexico, their contribution to the daily Se intake and the relationship of Se plasma levels and glutathione peroxidase activity. Nutr. Res. 1996, 16, 949-960.

(48) Tveitnes, S.; Singh, B. R.; Ruud, L. Selenium concentration in spring wheat as influenced by basal application and top dressing of selenium-enriched fertilizers. Fertilizer 
Research. 1995, 45, 163-167.

(49) Harn, M. H.; Kuennen, R. W.; Caruso, J. A.; Fricke, F. L. Determination of trace amounts of selenium in corn, lettuce, potatoes, soybeans, and wheat by hydride generation/condensation and flame atomic absorption spectrometry. J. Agr. Food Chem. 1981, 29, 792-796.

(50) Robinson, W. O. Selenium Content of Wheat from Various Parts of the World. Ind. Eng. Chem. 1936, 6, 736-738.

(51) Evenson, R. E.; Gollin, D. Assessing the Impact of the Green Revolution, 1960 to 2000. Sci. 2003, 300, 758-762.

(52) Galinha, C.; Freitas, M. C.; Pacheco, A. M. G.; Coutinho, J.; Ma S, B.; Almeida, A. S. Determination of selenium in bread-wheat samples grown under a Se-supplementation regime in actual field conditions. J Radioanal Nucl Ch. 2012, 291, 231-235.

(53) Von Uexküll, H. R.; Mutert, E. Global extent, development and economic impact of acid soils. Springer Netherlands. 1995, 171, 1-15.

(54) Wang, J. W. Effects of selenium and zinc on yield and mineral nutrition of main crops in dryland. In: Northwest A\&F University. 2012. (In Chinese).

(55) Souza, G. A.; Hart, J. J.; Carvalho, J. G.; Rutzke, M. A.; Albrecht, J. C.; Guilherme, L. R. G.; Kochian, L. V.; Li, L. Genotypic variation of zinc and selenium concentration in grains of Brazilian wheat lines. Plant Sci. 2014, 224, 27-35.

(56) Li, X. Z.; Wang, X. X.; Ma, S.; Ye, M. X. Effect of wheat peeling technology on selenium content in flour. Cereals \& Oils. 2017, 30, 50-54. (In Chinese).

(57) Hart, D. J.; Fairweather-Tait, S. J.; Broadley, M. R.; Dickinson, S. J.; Foot, I.; Knott, P.; 
532

McGrath, S. P.; Mowat, H.; Norman, K.; Scott, P. R.; Stroud, J. L.; Tucker, M.; White, P. J.; Zhao, F. J.; Hurst, R. Selenium concentration and speciation in biofortified flour and bread: Retention of selenium during grain biofortification, processing and production of Se-enriched food. Food Chem. 2011, 126, 1771-1778.

(58) Matos-Reyes, M. N.; Cervera, M. L.; Campos, R. C.; Guardia, M. Total content of As, $\mathrm{Sb}, \mathrm{Se}, \mathrm{Te}$ and $\mathrm{Bi}$ in Spanish vegetables, cereals and pulses and estimation of the contribution of these foods to the Mediterranean daily intake of trace elements. Food Chem. 2010, 122, 188-194.

(59) Wang, H. B.; Li, Q. L.; Liu, J. L.; Gan, P. Y.; Wang, Y. F.; Zhu, G. M. Development of kappa-selenocarrageen in premix and determination of se content in wheat flour and its products. Cereal \& Feed Industry. 2008, 6, 5-8. (In Chinese).

(60) Alamin, M. B.; Bejey, A. M.; Kučera, J.; Mizera, J. Determination of mercury and selenium in consumed food items in Libya using instrumental and radiochemical NAA. $J$. Radioanal. Nucl. Ch. 2006, 270, 143-146.

(61) Klapec, T.; Mandi, M. L.; Grgi, J.; Primorac, L.; Krstanovi, V. Selenium in selected foods grown or purchased in eastern Croatia. Food Chem. 2004, 85, 445-452.

(62) Murphy, J.; Cashman, K. D. Selenium content of a range of Irish foods. Food Chem. 2001, 74, 493-498.

(63) Díaz-Alarcón, J. P.; Navarro-Alarcón, M.; de la Serrana, H. L.; López-Martínez, M. C. Determination of selenium in cereals, legumes and dry fruits from southeastern Spain for calculation of daily dietary intake. Sci. Total Environ. 1996, 184, 183-189.

(64) Barclay, M. N. I.; MacPherson, A.; Dixon, J. Selenium Content of a Range of UK 
554 Foods. J. Food Compos. Anal. 1995, 8, 307-318.

555 (65) Oster, O.; Prellwitz, W. The daily dietary selenium intake of West German adults. Biol.

556 Trace Elem. Res. 1989, 20, 1-14.

557 (66) Arthur, D. Selenium Content of Canadian Foods. Canadian Institute of Food Science 558 and Technology Journal. 1972, 5, 165-169.

559 (67) Madaric, A.; Kadrabova, J.; Ginter, E. The selenium content of selected food from the 560 Slovak Republic. Food Chem. 1997, 58, 29-32.

561 (68) Gao, X. Y.; Gao, Q. Z.; Zhu, Y. R.; Wang, C. Q. Determination oftrace selenium content 562 in nanyang color wheat. Science and Technology of Cereals. Oils and Foods. 2015, 23, 67-70.

\section{3 (In Chinese).}

564 (69) Sager, M.; Werteker, M. Zur Elementverteilung in Mahlfraktionen von drei 565 Weizensorten an zwei niederösterreichischen Standorten. Nutrition. 2010, 34, 357-367.

566 (70) He, Y. The development and antioxidation of selenium rich biscuits. The Food Industry.

(71) Zhai, L. G.; Li, L. J.; Guo, Y. X.; Wang, J. Y.; Wang, B. C. Development of selenium-enriched rye crisp biscuit. Cereal \& Feed Industry. 2018, 11, 29-33. (In Chinese).

572 (73) Bryszewska, M. A.; Ambroziak, W.; Langford, N. J.; Baxter, M. J.; Colyer, A.; Lewis, 
576 Greek market and estimation of the daily intake. Sci. Total Environ. 2006, 372, 100-108.

577 (75) Holben, D. H.; Smith, A. M. The diverse role of selenium within selenoproteins: a 578 review. J Am Diet Assoc. 1999, 99, 836-843.

579 (76) Finley, J. W.; Matthys, L.; Shuler, T.; Korynta, E. Selenium content of foods purchased 580 in North Dakota. Nutr. Res. 1996, 16, 723-728. affecting the selenium intake of people in Transbaikalian Russia. Biol. Trace Elem. Res. 1994, 40, 277-285. Selenium in Finnish foods after beginning the use of selenate-supplemented fertilisers. $J$. Sci. Food Agr. 1991, 56, 57-70.

(79) Olson, O. E.; PALMER, I. S. Selenium in Foods Purchased or Produced in South Dakota. J. Food Sci. 1984, 49, 446-452.

(80) Ferretti, R. J.; Levander, O. A. Effect of milling and processing on the selenium content of grains and cereal products. J Agric Food Chem. 1974, 22, 1049. daily intakes among a population group. Food Chem. 1999, 65, 527-532. selenium content of wheat. Food Sci Tech-brazil. 2017, 42, 185-188. (In Chinese). 
(84) Kirby, J. K.; Lyons, G. H.; Karkkainen, M. P. Selenium speciation and bioavailability in biofortified products using species-unspecific isotope dilution and reverse phase ion pairing-inductively coupled plasma-mass spectrometry. J Agric Food Chem. 2008, 56, 1772.

(85) Hawkesford, M. J.; Zhao, F. Strategies for increasing the selenium content of wheat. J. Cereal Sci. 2007, 46, 282-292.

$$
\text { (86) D Az Huerta, V.; Hinojosa Reyes, L.; Marchante-Gay N, J. M.; Fern Ndez S Nchez, M. }
$$

A. L.; Sanz-Medel, A. Total determination and quantitative speciation analysis of selenium in yeast and wheat flour by isotope dilution analysis ICP-MS. J. Anal. Atom. Spectrom. 2003, 18, 1243-1247.

(87) Thiry, C.; Ruttens, A.; De Temmerman, L.; Schneider, Y.; Pussemier, L. Current knowledge in species-related bioavailability of selenium in food. Food Chem. 2012, 130, 767-784.

(88) Wrobel, J. K.; Power, R.; Toborek, M. Biological activity of selenium: Revisited. International Union of Biochemistry and Molecular Biology Life. 2016, 68, 97-105.

(89) Gerald, F. C. Biomarkers of Selenium Status. Nutrients. 2015, 7, 2209-2236.

(90) Shen, L.; Van Dyck, K.; Luten, J.; Deelstra, H. Diffusibility of selenate, selenite, seleno-methionine, and seleno-cystine during simulated gastrointestinal digestion. Biol Trace Elem Res. 1997, 58, 55-63.

(91) Artursson, P.; Karlsson, J. Correlation between oral drug absorption in humans and apparent drug permeability coefficients in human intestinal epithelial (Caco-2) cells. Biochem. Bioph. Res. Co. 1991, 175, 880-885.

(92) Thomson, C. D. Assessment of requirements for selenium and adequacy of selenium 
620

621

622

623

624

625

626

627

628

629

630

631

632

633

634

635

636

637

638

639

640

641

status: a review. Eur. J. Clin. Nutr. 2004, 58, 391-402.

(93) Meltzer, H. M.; Bibow, K.; Paulsen, I. T.; Mundal, H. H.; Norheim, G.; Holm, H. Different bioavailability in humans of wheat and fish selenium as measured by blood platelet response to increased dietary Se. Biol. Trace Elem. Res. 1993, 36, 229-241.

(94) Govasmark, E.; Brandt-Kjelsen, A.; Szpunar, J.; Bierla, K.; Vegarud, G.; Salbu, B. Bioaccessibility of Se from Se-enriched wheat and chicken meat. Pure Appl. Chem. 2010, 82, $461-471$.

(95) Sánchez-Martínez, M.; Pérez-Corona, T.; Cámara, C.; Madrid, Y. Preparation and Characterization of a Laboratory Scale Selenomethionine-Enriched Bread. Selenium Bioaccessibility. J Agric Food Chem. 2015, 63, 120-127.

(96) Burk, R. F.; Hill, K. E. Regulation of Selenium Metabolism and Transport. Annu. Rev. Nutr. 2015, 35, 109-34.

(97) Roman, M.; Jitaru, P.; Barbante, C. Selenium biochemistry and its role for human health. Metallomics. 2014, 6, 25-54.

(98) Rahavi, E. B.; Altman, J. M.; Stoody, E. E. Dietary Guidelines for Americans, 2015-2020: National Nutrition Guidelines. 2019.

(99) Zheng, S. J.; Yu, R. A.; Liu, X. L.; Zhou, J. C. Research progress on mechanisms of absorption and transportation of selenium. Chin Occup Med. 2013, 40, 456-460. (In Chinese).

(100) Cheng, M. W. Dietary patterns and their association with metabolic ayndrome among adults in China (2006-2009). National Institute for Nutririon and Health, Chinese Center for Diseases Control and Prevention. 2017. (In Chinese).

(101) Zhang, J. G. Changes in dietary patterns and their association with general and central 
642 obesity among adults in China (1991-2009). Chinese Center for Disease Control and 643 Prevention. 2013. (In Chinese).

644 (102) Filippini, T.; Cilloni, S.; Malavolti, M.; Violi, F.; Malagoli, C.; Tesauro, M.; Bottecchi, 645 I.; Ferrari, A.; Vescovi, L.; Vinceti, M. Dietary intake of cadmium, chromium, copper, 646 manganese, selenium and zinc in a Northern Italy community. J. Trace Elem. Med. Bio. 2018, $647 \quad 50,508-517$.

648 (103) Rivas, A.; Romero, A.; Mariscal-Arcas, M.; Monteagudo, C.; Lopez, G.; Lorenzo, M. 649 L.; Ocana-Peinado, F. M.; Olea-Serrano, F. Association between dietary antioxidant quality 650 score (DAQs) and bone mineral density in Spanish women. Nutr Hosp. 2012, 27, 1886-93.

651 (104) Gao, J.; Liu, Y.; Huang, Y.; Lin, Z. Q.; Banuelos, G. S.; Lam, H. W.; Yin, X. Daily 652 selenium intake in a moderate selenium deficiency area of Suzhou. China. Food Chem. 2011, $653 \quad 126,1088-1093$.

654 (105) Organization, G. W. H. Vitamin and mineral requirements in human nutrition. Geneva 655 World Health Organization. 2005.

656 (106) Ren, F.; Guo, X. Characteristics, toxicity and present situation of selenium in some 657 countries. Foreign Medical Sciences (Section of Medgeography). 2004, 3, 117-119. (In 658 Chinese).

659 (107) WS/T 578.3-2017. Chinese dietary reference intakes-Part 3: Trace element. (In 660 Chinese).

661 (108) Graham, R.; Senadhira, D.; Beebe, S.; Iglesias, C.; Monasterio, I. Breeding for 662 micronutrient density in edible portions of staple food crops: conventional approaches. Field 663 Crop. Res. 1999, 60, 57-80. 
664

665

666

(109) Sun, F. Y.; Chen, X.; Ma, Q. C.; Li, L., Wu, H. Y.; Li, T. Evaluation on Selenium

Biofortification Potential of Commercial Wheat Cultivars in Middle and Lower Reaches of the

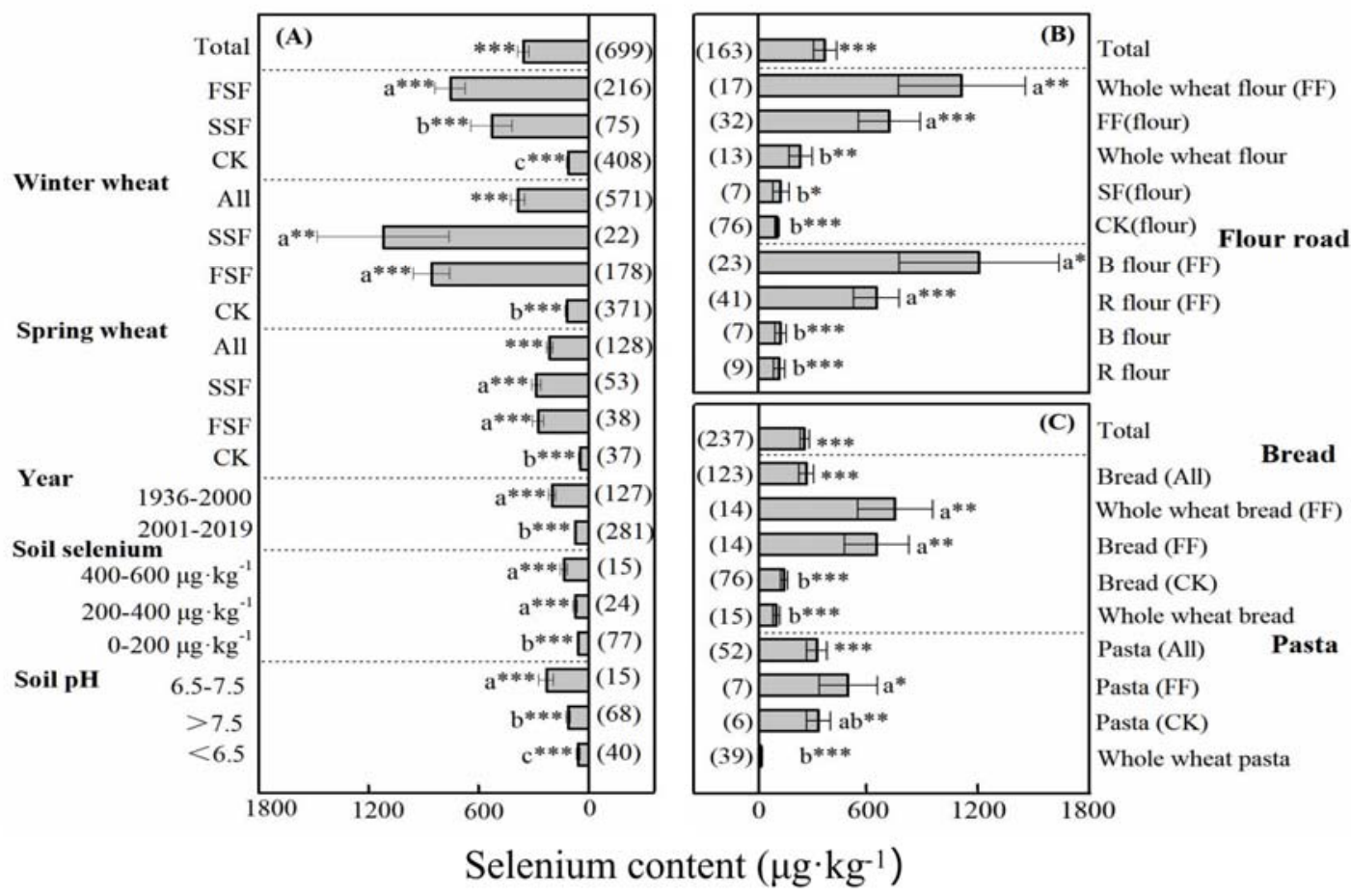

667

668

Figure 1 Comparison of Se content in wheat grain (A), flour (B) and food (C)

669

Note: Data originated from 66 studies; FSF: foliar Se fertilizer treatment, SSF: Soil Se

fertilizer treatment; CK: unfortified Se treatment; The year is based on the harvest year of

wheat; Data are presented as mean $\pm 95 \%$ CIs, with $\mathrm{n}$ in parentheses. Asterisks indicate 


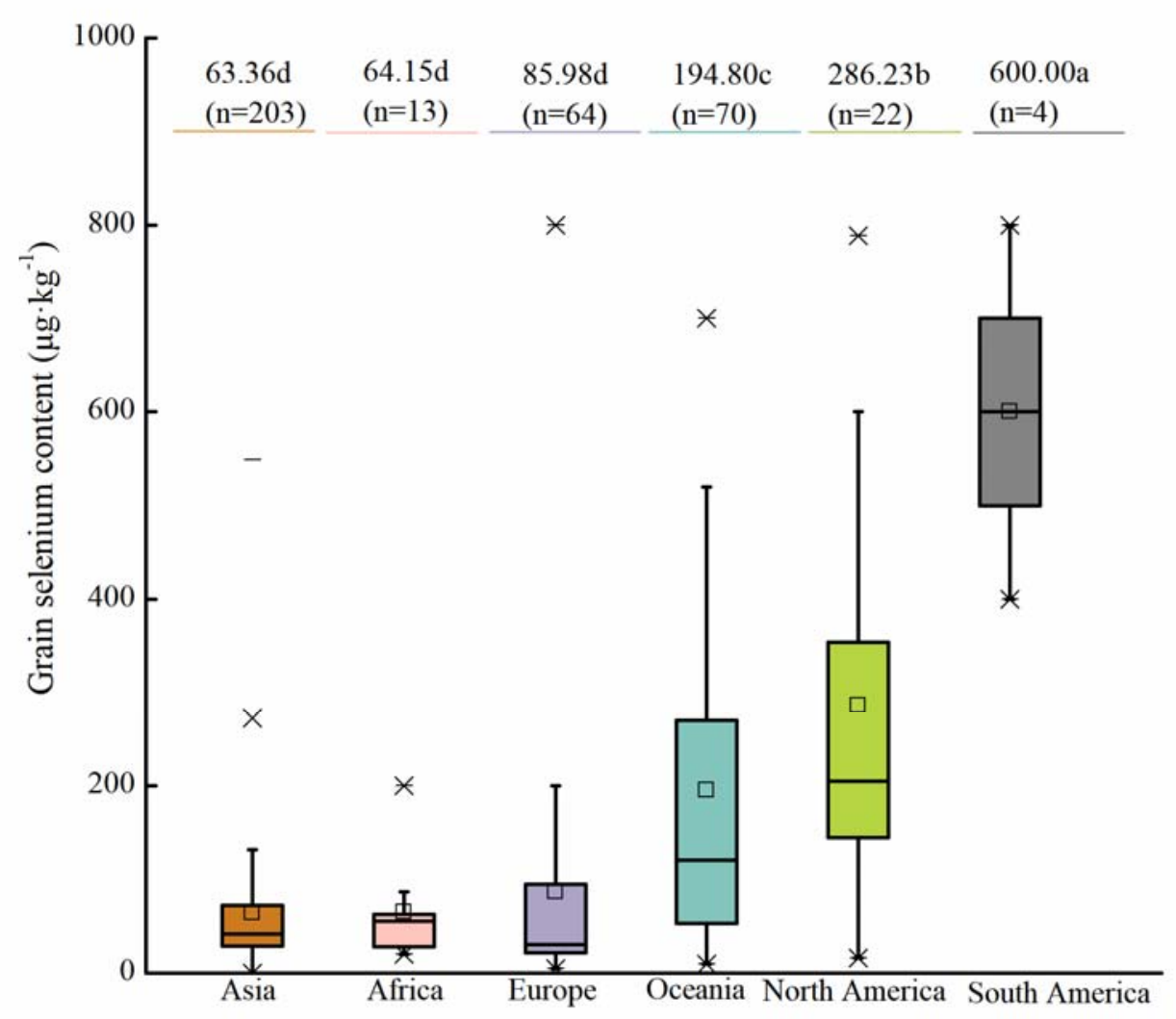

677

678 Figure 2 Selenium content of wheat among different continents

679 Note: Data originated from 42 studies; The letters a, b, c and d indicate a significant

680 difference at the level of $\mathrm{P}<0.05 ; \mathrm{n}$ is the total number of samples.

681

682

683

684 


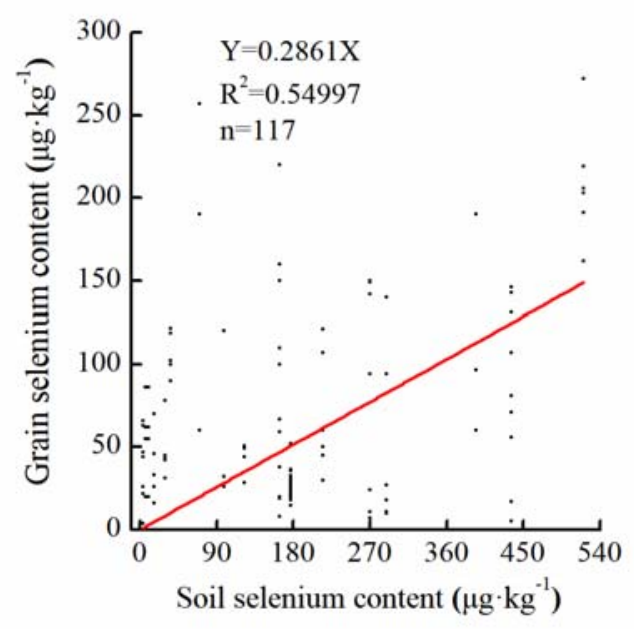

685

686 Figure 3 Relationship between soil selenium content and grain selenium content

Note: Data originated from 21 studies; $n$ is the total number of samples.
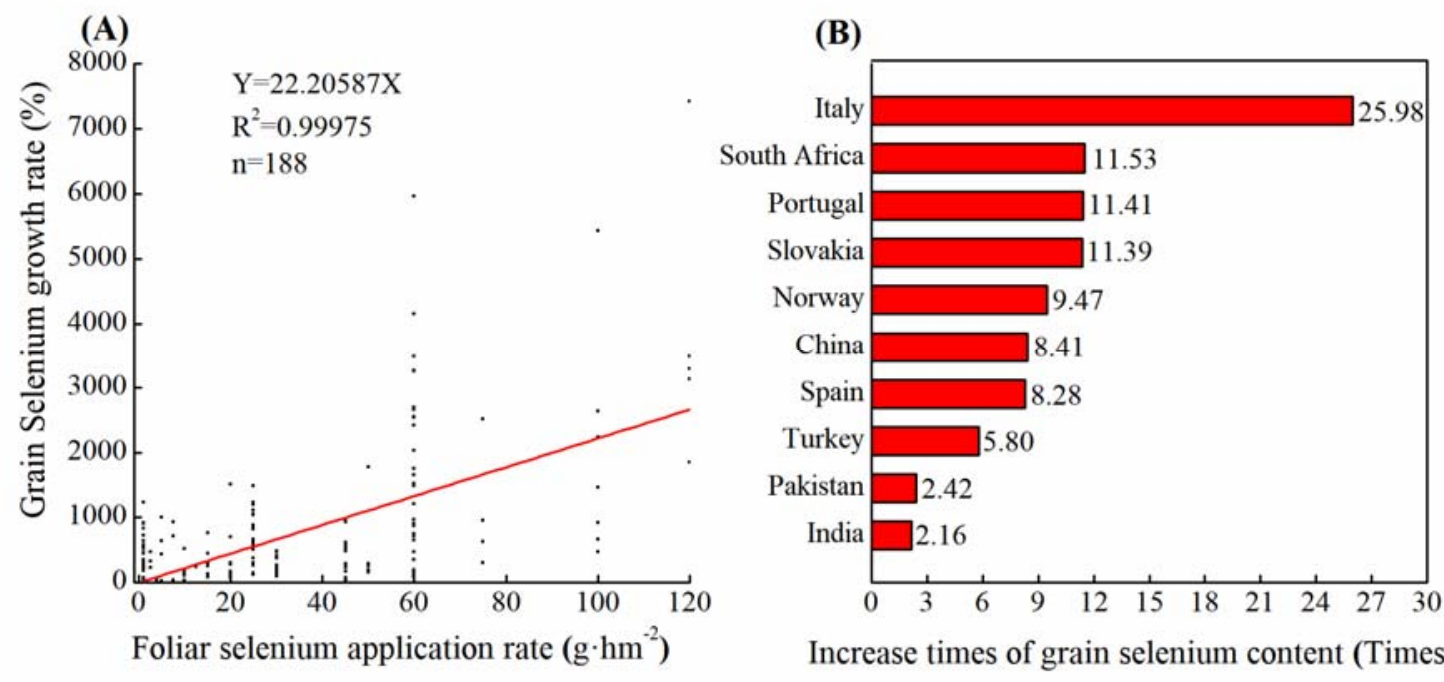

688

Figure 4 Relationship between foliar fertilization application rate and grain selenium content

(A) and increase times of grain selenium content after fortification in different countries (B)

Note: (A) Data originated from 21 studies; Selenium was added in the form of $\mathrm{Na}_{2} \mathrm{SO}_{3}$ 


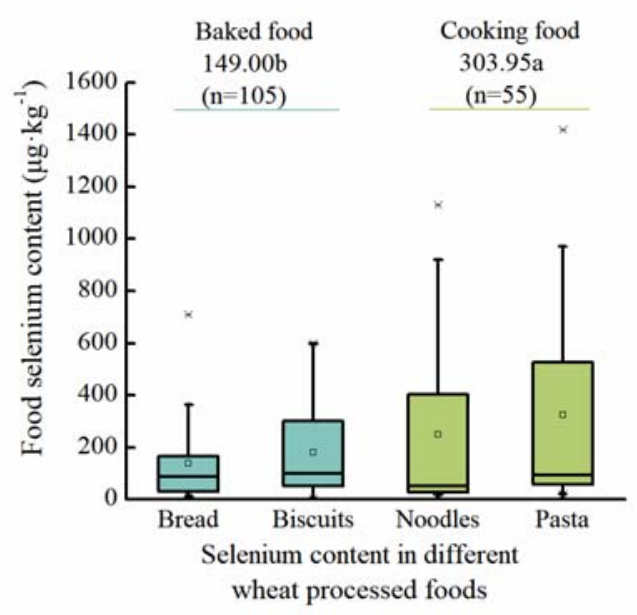

694

Figure 5 Selenium content in different wheat derived foods

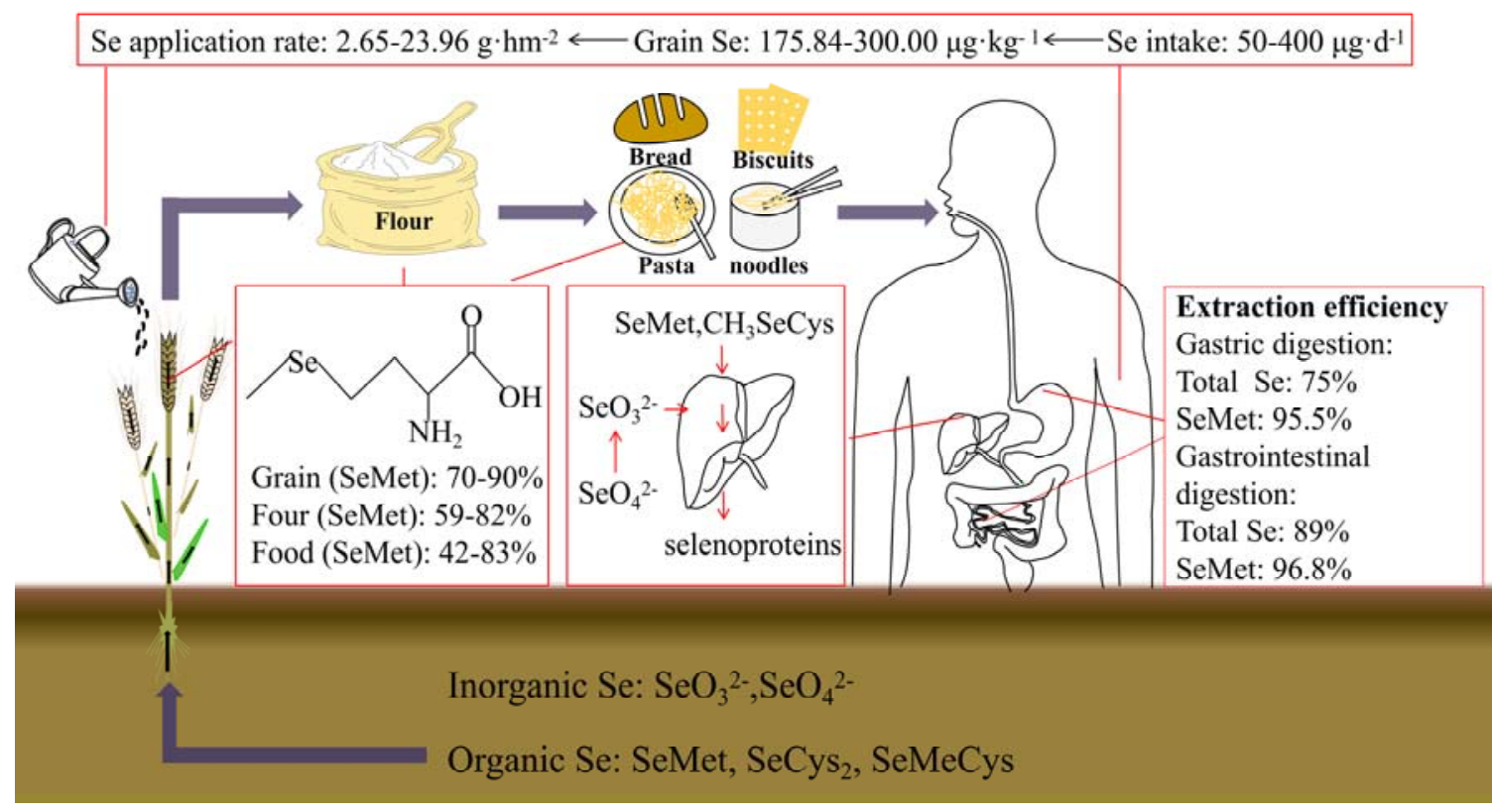

Figure 6 The change of selenium from grain to human body and the appropriate level of 
bioRxiv preprint doi: https://doi.org/10.1101/2021.07.17.452805; this version posted November 6, 2021. The copyright holder for this preprint (which was not certified by peer review) is the author/funder. All rights reserved. No reuse allowed without permission.

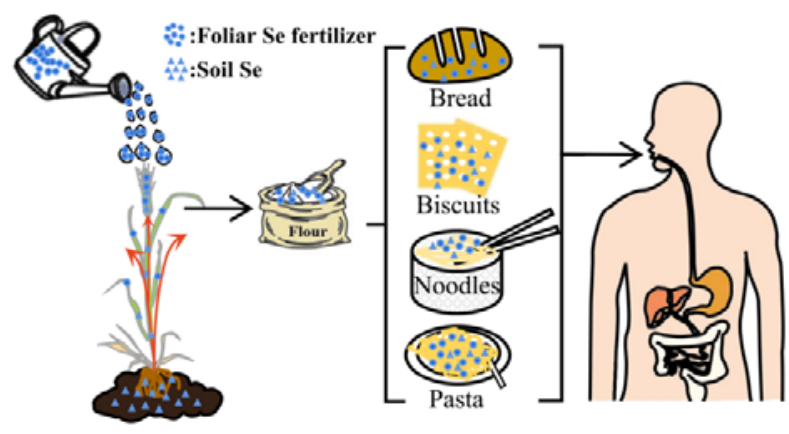

TOC graphic 


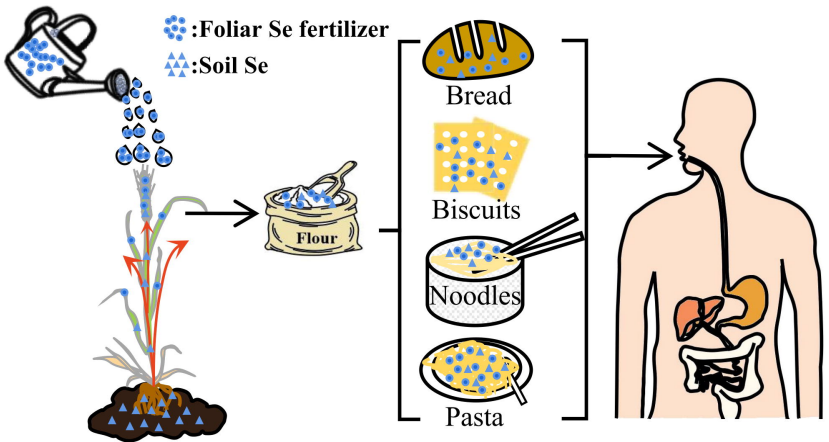




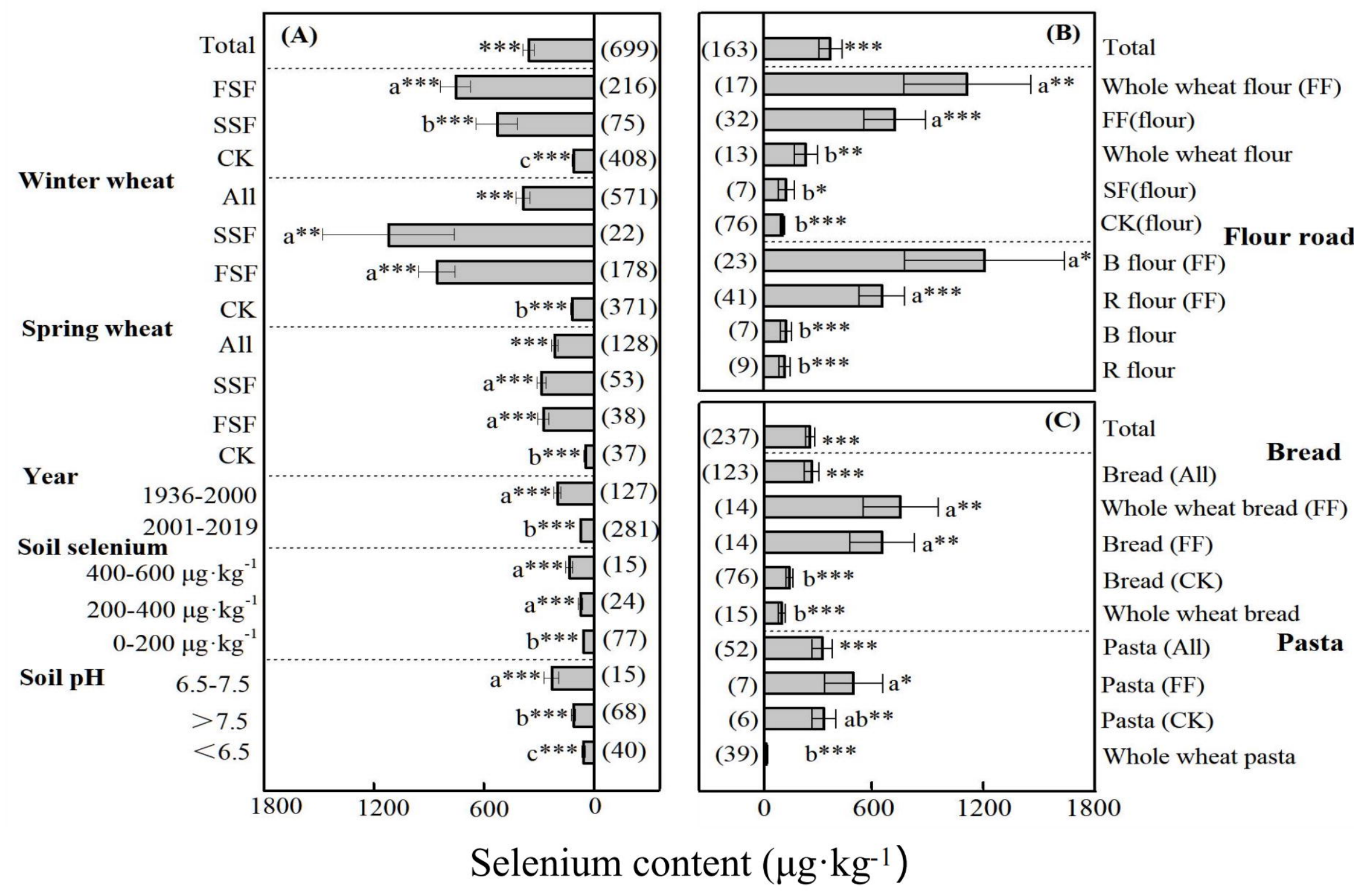




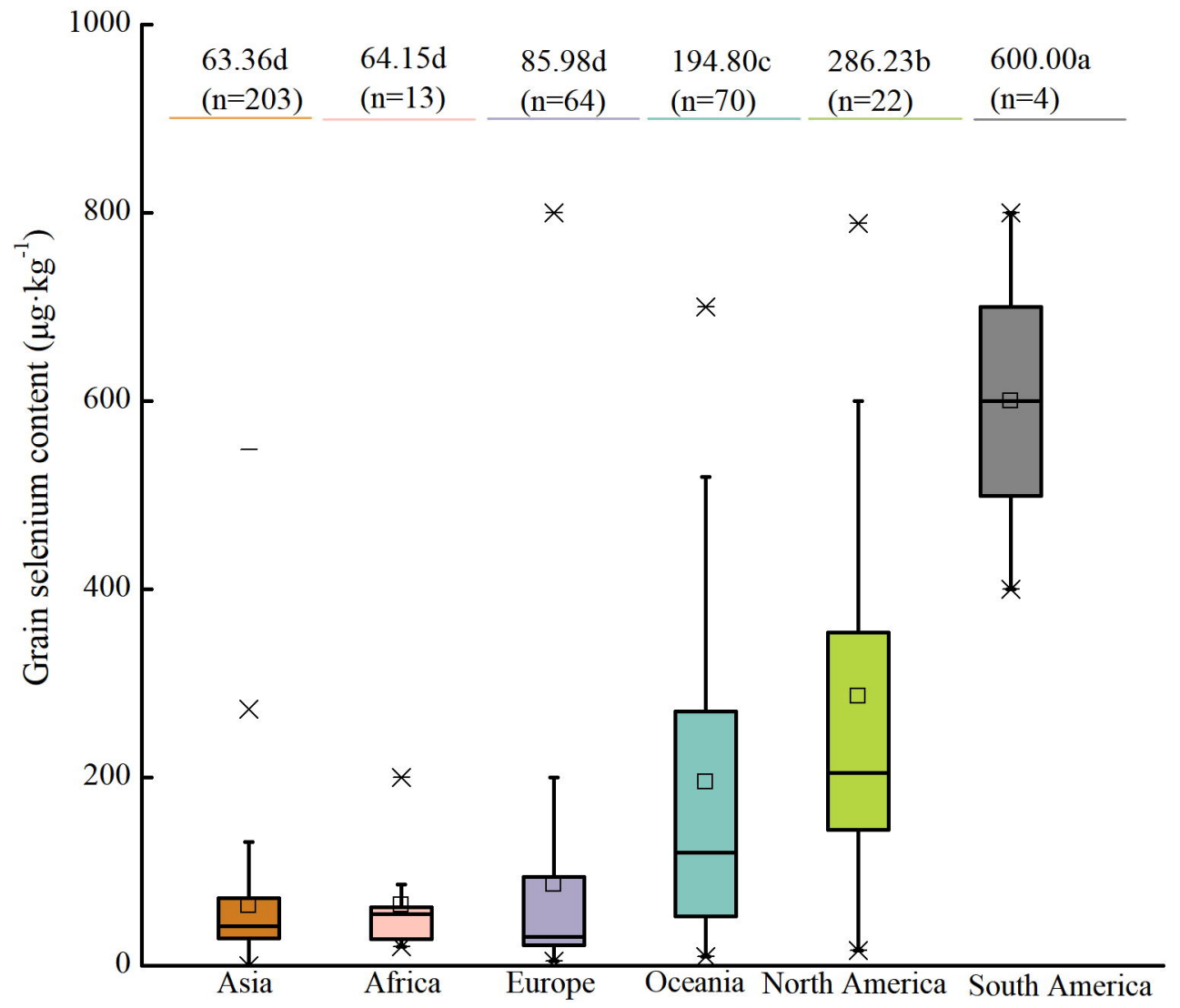




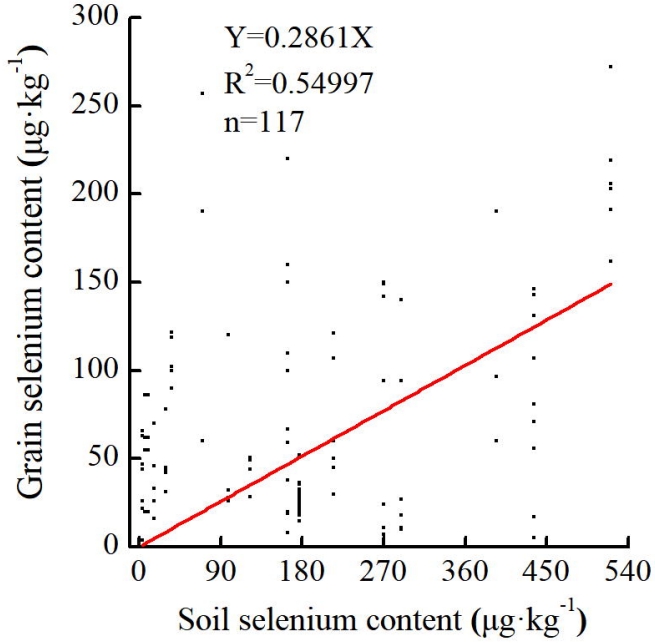


(A)

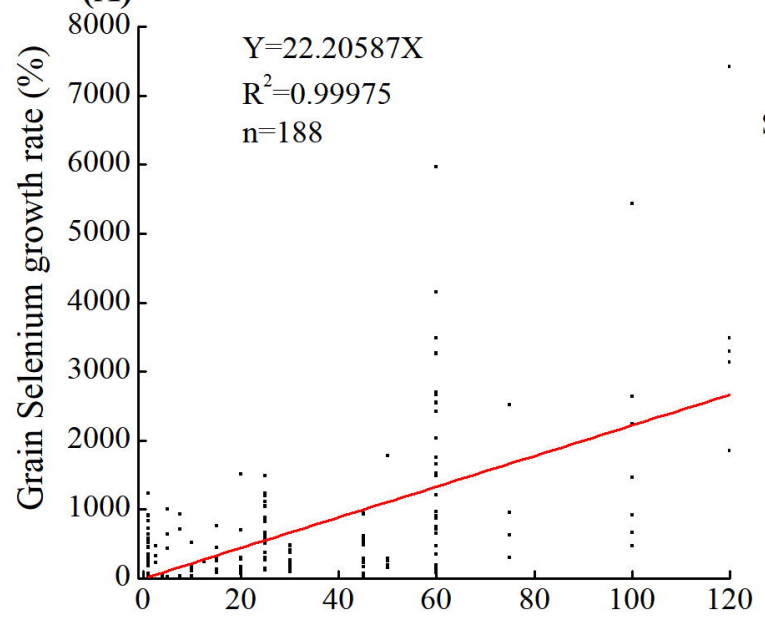

Foliar selenium application rate $\left(\mathrm{g} \cdot \mathrm{hm}^{-2}\right)$
(B)

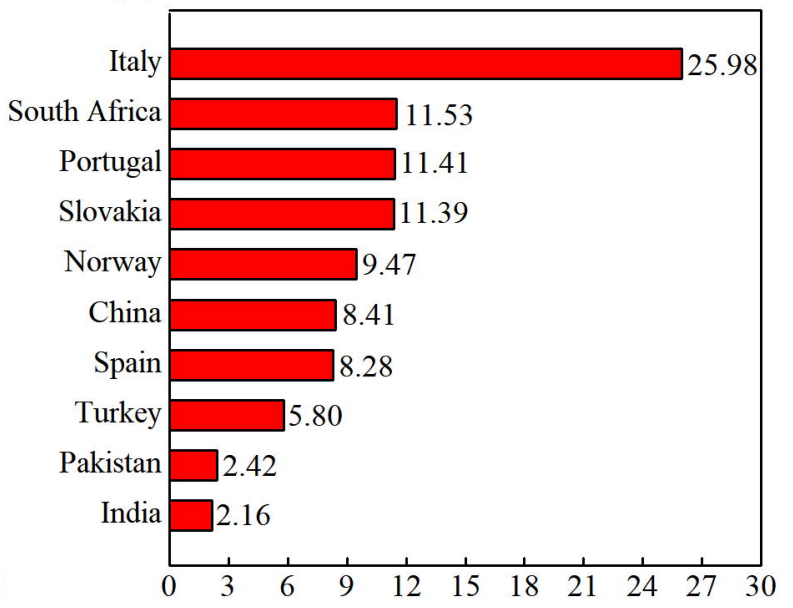

Increase times of grain selenium content (Times) 


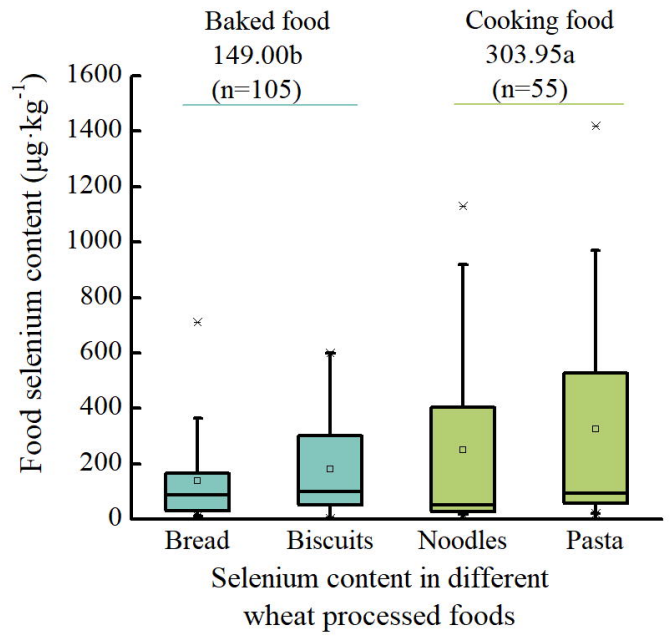




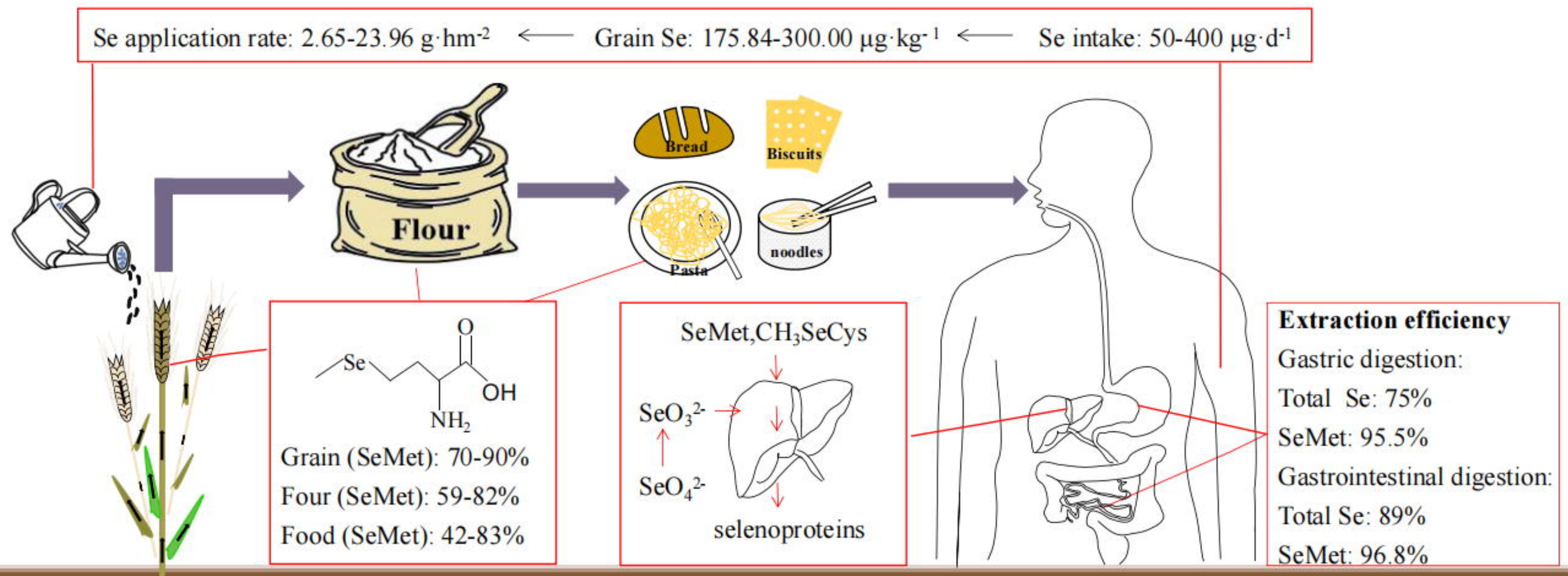

Inorganic $\mathrm{Se}: \mathrm{SeO}_{3}{ }^{2-}, \mathrm{SeO}_{4}{ }^{2-}$

Organic Se: SeMet, SeCys 2 , SeMeCys 